\title{
Promoting Critical Reading Strategy in Literacy Based-Writing Instruction: Indonesian Context
}

\author{
Henri Fatkurochman \\ Universitas Muhammadiyah Jember \\ (henrifatkurochman@unmuhjember.ac.id)
}

\begin{abstract}
Teaching writing English as a foreign language (EFL) in university setting aims to achieve both linguistic and literacy competencies. It means that the instruction not only focuses on facilitating students to build writing English proficiency, but also on leading students to become literate. Based on this context, it is important for lecturers to select appropriate and effective strategies in the writing instruction. Critical reading is regarded as meaningful and effective reading strategy which can be applied by academic writing instructors or lecturers in order to enable the students in writing an English-written paper. This article attempts to discuss why and how critical reading strategy should be utilized in literacy model of EFL writing instruction, especially in writing a research paper. By understanding the relationship between reading and writing, it is hoped that the activities in the EFL writing classroom can be more meaningful.
\end{abstract}

Keywords: critical reading; literacy-based writing instruction.

Writing lecturers of EFL classroom frequently face challenging conditions in implementing meaningful activities in writing instruction. The EFL writing classroom is widely recognized by the act of revision of the student writing product in terms of vocabulary, grammar, text structure, and style. In addition, lack of effective teaching strategy and insufficient technique often occur. This phenomenon is largely found in Indonesian schools and universities.

In the context of writing EFL in higher education, the instruction are expected to achieve literacy competency. This means that the writing instruction should lead to communicative orientation. However, the way usually implemented is giving the example of text to learn. For the next step, the lecturers instruct the students to write the text similar to the given example. Actually, this kind of instruction aims to make students familiar with text types. However, the common problem that the students faced is that they are stuck in writing process. This occurs because they find it difficult to develop ideas as the main material in writing. The other problem is that they only imitate the writing product without any creativity. As a consequent, they regularly copy the example in order to produce writing text. 
Reading has a close connection with writing. Many researches showed that reading skill has significant contribution to writing competence. All good writers are those who have done large amount of pleasure reading (Krashen, 1981). He noted further that reading remains the only way of developing competence in writing. For students of higher education, reading is really the most important activity (Fairbairn, 2001). In higher level learning, the students normally encounter various texts to learn, to response, and to criticize. Moreover, they can be used to create information gap leading to communicative activities (Raimes, 1983). Therefore, the relationship between reading and writing is that of parallel or complementary processes (Kucer, 2005). However, it does not mean that reading is directly helping learners become better writers. Significant practice and instruction is still needed to become proficient (William, 2003). So it is clear that reading indisputably contributes to increase students writing proficiency.

Critical reading is understood as the core activity in literacy-based model of writing. It is recommended to upgrade writing competence for several reasons: 1) it can stimulate idea, 2) it helps to improve writing style, and 3) it can contextualize argument and viewpoint in our writing (Fairbairn, 2001). Reading critically is considered coincide with higher level learning in which the learners are prompted to provide critical analysis on written text. By critical reading, the learners not only recognize linguistic features (vocabulary, grammatical structures, and styles), but through continued process they also make use of the written text to relate information from the text (content) with their prior knowledge. Moreover, it provides students with meaningful experience to construct ideas.

In a process-oriented writing instruction, reading and writing (notetaking) support each other and can be done in sequence. In the earlier stage, note-taking is advantageous for learners to highlight key words in the written text and to find the main idea; and in the advanced one, it can exercise the learners to note the writer's mistakes and interesting point of view. Finally, through note-taking the students can generate and develop ideas.

This article attempts to provide an understanding on the importance of critical reading strategy implemented in literacybased model in teaching writing a research paper' on the Indonesian university setting. Furthermore, it aims to promote why this model of instruction should be adopted in the EFL writing classroom. Hopefully, lecturers and instructors can prepare meaningful activities for their students to develop writing competence.

\section{Discussion}

Writing Instruction in Indonesian Context: Towards Literacy-Based Model

Examining the local setting of writing instruction is crucial to introduce a new concept in order to integrate it into the existing material and conceptual structures (Nauman, 2011). In higher education, there are three models of student writing: 1) study skills, 2) academic socialization, and 3) academic literacies (Cumming, 2006). The study skill model focuses on psychological and linguistic theories. This model sees writing as atomized skills and surface features of texts and language. Meanwhile, the academic socialization model places students into a new culture to become functioning members of a particular academic discourse community and its institutional norms, genres, and practices for writing. On the other hand, in the academic literacies model, it portraits students as negotiating conflicting power relations and different literacy practices to develop and challenge a variety of differing repertoires for writing as well as identities appropriate to diverse models of discourse and relations.

Besides understanding the models of student writing, it is also crucial to attend the approach. There are commonly three 
influential approaches to student writing: 1) writing as text, 2) writing as process, and 3) writing as social practice. The writing as text approach emphasizes students' writing as final products. The students are provided with good examples of writing to imitate. The focus is on the written text and little analysis on rhetorical aspect and social context of the text. Writing as process focuses on how the students can express their identity, while writing as social practice focuses on writing as social activity. According to Coffin et al. (2003), in the context of higher education, writing as social practice can be seen in three different ways. First, student writing is always connected with teaching and learning that influence the students' success to write. Second, appropriate academic writing is social activity to the extent that should be developed within academic communities. Third, student academic writing is social practice in which the students are learning to communicate with writers as well as how to write as academic. Thus, these writing approaches can be taken and suited to the purpose of writing pedagogy and instruction.

For university students, writing is important to support any course tasks accomplishment. In Indonesia, it is usual phenomenon that lecturers give the tasks in scientific paper writing. In this setting, it is urgent for learners to study some various types of academic written text. Indonesian education has traditionally valued learning through reading text. Through written text, EFL students study about language and how the language is used. They are intended to write in English as the exemplars given to them, so that the instruction is frequently given by explaining text types; and the students are exercised to compose those sorts of texts without giving much opportunities to critical analysis. Such kind of writing instruction is possible to develop only linguistic competence. In fact, the students might be successful in text interaction, but they do not communicate their knowledge to the author's view within the text. Consequently, the writing instruction only values text as the main resource to build writing English skill, not as a tool to develop expected-writing competency. In reality, the students still find it difficult in making paraphrases, analyses, and syntheses in their writing.

Accordingly, the writing instruction in higher education should not be separated from literacy purpose. In current policy, the university students should write a scientific article published in journals. Even in many Indonesian universities, it is a must for graduate and post-graduate students to have scientific publication. Thus, it is crucial for EFL writing instruction to adopt academic literacies model. It fully involves communication and interpretation. Additionally, Nauman (2011), quoting Kern, states that literacy has seven fundamental principles: collaborative, interpretive, involving conventions, cultural knowledge, problem solving, reflection and self-reflection, and language use. More general, Kucer (2005) noted that literacy involves four dimensions: cognitive, linguistic, sociocultural, and developmental. Thus, literacy model in writing instruction is more advanced than individual acts of meaning making and language use.

Literacy-based writing instruction in EFL context is framed to accommodate practices which activate learner's cognitive, explore social context in which English is being employed, and construct relations with written text. In this model, the writing instructor should facilitate learners of English, as readers, to be able to communicate successfully with the writer in order to achieve the development on writing competence.

\section{Understanding Discourse Production}

One of the main purposes of the literacy model is discourse production. Different to the usual model of writing instruction, it is started with exposing several variations of texts rather than to directly writing. Based on Kucer (2005) conception, there are five addressed features for both reading and writing. They are knowledge 
search, context, goals and plans, strategies, and evolving text. These features are considerable to develop discourse production and can be addressed to reading and writing.

As reading is initiated, the searching of knowledge occurs. When readers read, they evaluate their schemata with the new information they encountered. For Kucer, schemata is simply defined as the knowledge of the world. This knowledge is implicitly and explicitly culturally coded. As background knowledge is available, one can evaluate its relevance and appropriateness. Thus, during the process of reading, the reader continually evaluates the background knowledge for understanding the text. They also utilize meanings and relationships that have been discovered through their engagements with the text.

Reading is a process to grab meaning from the text. It is obviously an act of meaning making. A reader faces not only the written text but also the context. While reading, there is a transaction between language users and context of situation. More detail on the nature of reading, Kucer (2005, p. 125) explains:

As the individual searches available background knowledge, he or she evaluates its relevance and appropriateness. For the reader, the background must support the construction of a plausible interpretation for the print being encountered. During the process of reading, as new information is encountered, the reader continually evaluates the background knowledge being used to support an understandings only from what is already known. They also utilize meanings and relationships that has been discovered through their engagements with the text. Simply by reading, readers come to see what was not previously seen.

The explanation conveys an understanding that reading is an act of collecting new information in order to find new understandings by interpreting the encountered information.

Another feature in reading is that reading is not free from goal and plan. A text has various purposes. On the other hand, a reader has an intention. One will read a text appropriate with his/her intention. Therefore, while reading a reader should determine some plans he/she will operate. The way how to read is usually planned by the readers. It is actually matched with their purpose. According to Kucer (2005), (Kucer, 2005), both plans and their corresponding goals serve as 'a control mechanism' that give direction to the readers to search for meaning.

As goal and plan provide directionally to reading, strategies follow. The reading strategy is defined as processing procedures by which the reader operates to obtain information from the text. The reader use it to build deep structure (meanings) from the surface structure of the written text. Through creating the evolving new text, meaning can be monitored, evaluated, and revised.

The features of discourse production provides conceptual basis to literacy-based model of instruction. Based on that conception, teaching writing cannot be separated from engaging the students in the reading process because reading is coherent with producing written discourse.

\section{Why Critical Reading?}

Teaching writing 'research paper' is commonly given in order to give students a skill to produce an acceptable writing discourse. It consequently requires an effective effort in the instruction. The lecturers are expected to bring the students write a paper in particular academic style. Additionally, the instruction should accommodate their research design for further discussion. For this demand, it is possible to complete process and product approach with literacy-based model of writing instruction.

In literacy-based model, critical 
reading is as the most important activity. It is a reading strategy in which students read written materials critically. So in the process of reading a text, they do communicate with the author rather than just accept the author's opinions. Learners as critical readers can question, debate, and examine evidences. While reading, students activates their metacognitive to respond to the text. Such activity mediates the students to relate what has been read with the information they had, so that they build communication on the cognitive level. In general, communicative competence relates closely to the negotiation of meaning and the relation between interlocutors, in the sense of the writers' message and the readers' interpretation. Reading can be used to create information gap that leads to communicative activities (Raimes, 1983). He added that, with reading, students are engaged actively in new language and culture. What can be done by students in this technique is underlining the highlights, making a summary, questioning a concept, commenting, and making some critical notes for clarity. This will lead to familiarity to write interpretively. Thus, critical reading can be understood as reading to communicate as well as reading to interpret.

Critical reading activity implies a productive act than rewrite what is in the text. When students read written discourse, they can examine their prior knowledge and the information found in the text by taking notes or writing an account of what they have read. Consequently, taking notes is part of reading, thus is essentially readers' responsibility, meaning that students as readers are in charge of giving valuable comments. This step provides students a chance to write based on their own interpretation.

So, critical reading is recommended in literacy-based model of writing instruction. Specifically in teaching writing a research paper, the strategy is in line with the university level of learning that exposes critical thinking to making analysissynthesis of the given issues.

\section{Application in the EFL Writing Classroom}

Based on the earlier explanation, critical reading is applied in the EFL writing instruction because of several reasons. First, it promotes to cognitive enhancement. Second, it provides opportunity to text exposures. Third, it exercises of making analysis-synthesis. These three points are fundamental in the process of writing a research paper.

In practice, critical reading should be applied in the whole process of the course. However, many Indonesian students are still not familiar reading journal. So in the very beginning of the course, giving examples of articles is extremely required. This step is taken to expose the students to a specific genre of English written text in pre-writing phase. Its purpose is to enable the students recognize the structure and style of the journal articles. The focus of instruction is on the text type. This is an important step because the students will publish their research paper on scientific journal.

In the next step, the lecturer can give the students a task to review some articles having relation to their topic of interest. To do that the students are given the available link of recommended journals in order they can browse related articles. Then they are instructed to read three to five articles in different journal and explore critical issues in the articles. In this step, the students activate critical reading strategy by questioning, comparing, discuss, and evaluating the concept. In this step, they are exercised to find the highlights of the content of the text. The focus of the instruction is on the content understanding. Since the students enhance their cognitive, it will be easier for them to generate ideas. In Kucer's (2005) conception, they make a transaction to the context of situation. This enables the students to find new concepts to develop writing.

In the writing phase, critical reading activity can also be done in peer review. This is a session in which the student reader evaluates 
critically their peer writing and give feedback. Although the given feedback is minimum and limited to grammatical correction rather than on rhetoric aspect, this practice is relatively meaningful to student writers (Fatkurochman, 2015). By reading the peer's draft of writing, the students monitor their metacognitive development and self-reflection/correction. According to Hyland (2003), the goal of this is to encourage negotiation of rhetorical planning.

Thus, critical reading strategy has a great possibility to implement in the EFL writing classroom. It can be done repeatedly in the process of writing a research paper. Indeed, critical reading that promotes critical thinking would be so advantageous to construct arguments needed to increase the quality of a research paper.

\section{Conclusion}

Writing instructional practices in the majority of Indonesian universities still apply the traditional method of teaching. Giving an amount of tasks to the learners without any comments and responses either from peers and lecturers is a general phenomenon in the EFL writing classroom
Since the Indonesian universities are required to support literacy movement, the model of teaching and learning must also be improved. In this regard, teaching writing a research paper, should be developed into literacy-based model of writing instruction. Otherwise, it might not achieve highlyqualified writing product. Therefore, as the core of literacy, critical reading strategy that coincides to critical thinking is crucially utilized to achieve literacy competence.

Last but not least, critical reading strategy should always be promoted to apply in the EFL writing instruction using literacybased model. To do this, lecturers of writing instruction should also be literate and facilitate various scientific journal articles for the students reading to make them familiar with specific written discourse.
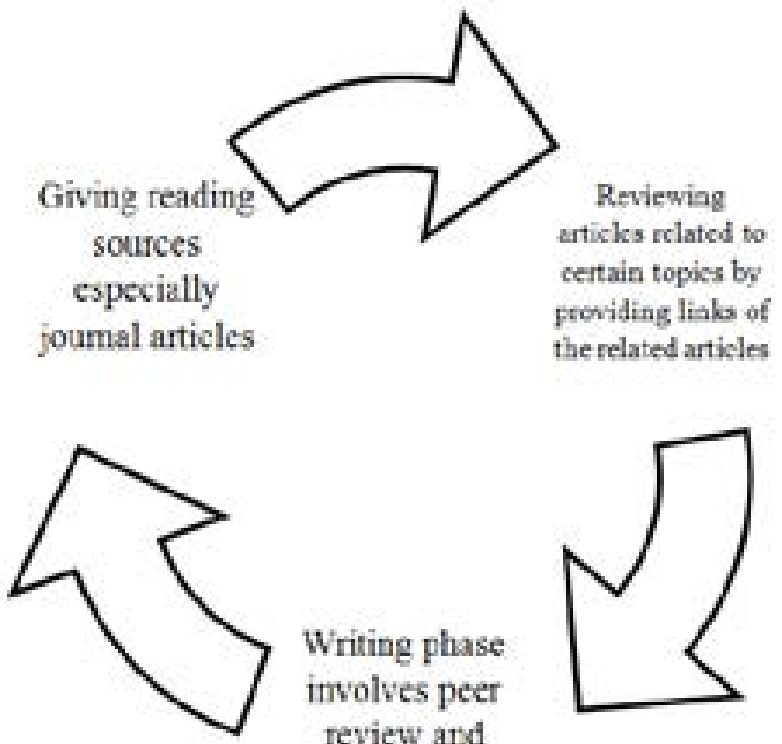

Writing phase involves peer review and

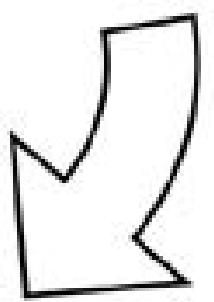
giving feedback

Figure 1. Phases Proposed for Improving Critical Thinking through Writing 


\section{References}

Caroline, Coffin M. J. (2003). Teaching Academic Writing: a Toolkit for Higher Education. London: Routledge.

Cumming, A. (2006). Goals for Academic Writing ESL Students and Their Instruction. Philadelphia: John Benjamins Publishing Company.

Fairbairn, G. J. (2001). Reading at University: A Guide for Students. Maidenhead: Open University Press.

Fatkurochman, H. (2015). Peer Response as an Authentic Assessment in a Process Approach Writing Classroom. Didaktika, 67-75.

Hyland, K. (2003). Second Language Writing. Cambridge: Cambridge University Press.

Krashen, S. (1981). The role of input (reading) and instruction in developing writing ability (Working paper). Los Angeles: University of Southern California.

Kucer, S. B. (2005). Dimension of Literacy: A Conceptual Base for Teaching Reading and Writing in School Settings. Mahwah, New Jersey: Lawrence Erlbaum Associates, Publishers.

Nauman, G. (2011). Synthesizing the Academic and the Everyday: A Chinese Teacher's Developing Conceptualizing of Literacy. In K. E. Golombek, Research on Second Language Teacher Education: A Sociocultural Perspective on Professional Development (pp. 102-117). New York: Routledge.

Raimes, A. (1983). Techniques in Teaching Writing. Oxford: Oxord University Press.

William, J. D. (2003). Preparing to Teach Writing. Mahwah, New Jersey: Lawrence Erlbaum Associates, Publisher. 
